\title{
Article \\ A Long-Term Symbiotic Relationship: Recruitment and Fidelity of the Crab Trapezia on Its Coral Host Pocillopora
}

\author{
H. M. Canizales-Flores ${ }^{1}$ (D) A. P. Rodríguez-Troncoso ${ }^{1, *(\mathbb{D})}$, F. A. Rodríguez-Zaragoza ${ }^{2}(\mathbb{D}$ \\ and A. L. Cupul-Magaña ${ }^{1}$ (D)
}

1 Laboratorio de Ecología Marina, Centro Universitario de la Costa, Universidad de Guadalajara, Av. Universidad No. 203, Puerto Vallarta 48280, Mexico; hazel_mariacf@hotmail.com (H.M.C.-F.); amilcar.cupul@gmail.com (A.L.C.-M.)

2 Laboratorio de Ecología Molecular, Microbiología y Taxonomía (LEMITAX), Departamento de Ecología, Centro Universitario de Ciencias Biológicas y Agropecuarias, Universidad de Guadalajara, Camino Ramón Padilla Sánchez No. 2100 Nextipac, Zapopan 45110, Mexico; fabian.rzaragoza@academicos.udg.mx

* Correspondence: pao.rodriguezt@gmail.com or alma.rtroncoso@academicos.udg.mx; Tel.: +52-3222262319

Citation: Canizales-Flores, H.M.; Rodríguez-Troncoso, A.P.; Rodríguez-Zaragoza, F.A.; Cupul-Magaña, A.L. A Long-Term Symbiotic Relationship: Recruitment and Fidelity of the Crab Trapezia on Its Coral Host Pocillopora. Diversity 2021, 13, 450. https://doi.org/10.3390/ d13090450

Academic Editors: Michael Wink, Patricia Briones-Fourzán and Michel E. Hendrickx

Received: 30 August 2021

Accepted: 15 September 2021

Published: 19 September 2021

Publisher's Note: MDPI stays neutral with regard to jurisdictional claims in published maps and institutional affiliations.

Copyright: (c) 2021 by the authors. Licensee MDPI, Basel, Switzerland. This article is an open access article distributed under the terms and conditions of the Creative Commons Attribution (CC BY) license (https:// creativecommons.org/licenses/by/ $4.0 /)$.
Abstract: The symbiotic relationship between the crab Trapezia spp. and pocilloporid corals has been characterized as obligate. Although this relationship is considered common and has been widely registered within the distribution areas of these corals, the initiation of this symbiotic relation and its potential persistence throughout the life cycle of the crustacean is still poorly described. To understand the Trapezia-Pocillopora symbiosis, determining the time and conditions when Trapezia recruits a coral colony and the factors influencing this process are key. Thus, in the present study, healthy, small and unrecruited coral fragments were attached to the substrates (using cable ties) of nearby adult Pocillopora colonies. All fragments were monitored for two years to measure their growth and size at the first evidence of Trapezia crab recruitment, as well as the abundance and permanence of the crabs on the coral fragments. Results showed a relation between the space available (coral volume) and crab recruitment as an increase in substrate complexity is required to provide protection for the crabs and hence maintain the symbiosis, while abiotic conditions such as sea temperature and the distance of the fragments from the adult coral colonies seemingly did not affect the recruitment process. In addition, crabs are able to move between colonies, thus discarding the theory that once recruited, crabs are obligate residents on this specific colony.

Keywords: ecology; symbiosis; crustacean; crab; coral

\section{Introduction}

Invertebrates are the most abundant and diverse group within coral reefs [1]; some of them are considered obligate associates on live corals [2] and their distribution has been fully attributed to the presence of their host [3-5]. However, their abundance and permanence not only depend on the presence of the host but also on (1) their reproduction and recruitment, both regulated by abiotic factors, and (2) the ability of the larvae to disperse, recognize and occupy suitable substrates [6]. Specifically, the benefits coral colonies provide for their commensals, in comparison to free-living species, are a permanent shelter, nursery site and in some cases nourishment $[7,8]$.

Moreover, the obligate association invertebrate-corals can be characterized as bidirectional. In particular, different groups of crustaceans have been reported to engage in symbiotic associations with other macroinvertebrates such as sponges, sea anemones and echinoderms, among others [9]. The benefit of these symbiotic assemblages may determine their hosts' fitness and long-term survival [5]. Hermatypic corals are the base of coral communities; however, their permanence depends not only on the coral response but also on their associated organisms. The presence of hydrozoa appears to reduce the corals susceptibility to diseases [10]. In the specific case of crustaceans, they have a relevant 
role in the daily maintenance of the colonies as they cleanse sediments and protect them from predators $[11,12]$ but also have a major role as their presence can slow down the progression of white syndrome, as observed in Acroporids [13]. Therefore, the presence of a high diversity of crustaceans, not only at a species level but also at a size level, can decrease the vulnerability of the coral to different local stressors [14]. The accurate characterization of the diversity of coral-associated organisms possibly contributes not only to an increase of the knowledge on the ecology or physiology of a specific group but also to the different mechanisms controlling coral reef functioning [5].

Trapezia spp. crabs are considered both highly abundant and conspicuous brachyuran crustaceans, with a well-documented specific association as defenders of pocilloporid corals $[14,15]$. The success of the Pocillopora-Trapezia symbiosis results from the fact that the crabs share distribution with Pocillopora, the most abundant genus along the Eastern Tropical Pacific [16], and also from their functional role in this symbiosis. The coral harbors the crab, but in exchange, Trapezia crabs use Pocillopora colonies as a specific substrate for refuge, as a feeding ground for grazing or food capture and as a direct source of nutrition (detrital sludge, algae, etc.) [17]. In return, Trapezia eliminates the excess of sediment and detritus accumulated on the coral tissue, thus contributing to the fitness of their Pocillopora host and resulting in higher coral growth rates and an increase in their resistance to thermal stress and bleaching [18].

Trapezia crab reproduction, recruitment and even migration responses are influenced by annual changes in sea surface temperature and salinity [19]. Brachyuran reproduction includes a planktonic larval phase that can last in the water column for days or weeks, thus contributing to their local and regional dispersion [19]. Subsequently, the competent larvae will detect specific chemical cues to settle and recruit [20]. In general, in tropical areas, invertebrate larvae develop and settle during the warm season as temperature is a trigger for their reproductive activity [21] and also due to food availability for both the larvae and the early recruited organisms [1]. On the other hand, at sub-tropical coral reefs, it has been demonstrated that there are no specific temporal patterns for crustacean recruitment [22]. Therefore, recruitment depends on the organism's ability to reproduce and the optimal environmental conditions, but the availability and suitability of the substrate also represent an important factor for determining the species' abundance and composition.

Despite the relevance and life-long permanence of Trapezia crabs in coral communities, studies regarding their recruitment and other behavior such as migration are scarce and restricted to the presence, density, abundance at the coral genus level and the potential relationship between crabs, coral colony size and available space [23]. When recruited, crabs develop territorial behavior, protecting their host from both predators and intraspecific competitors [8]. However, Trapezia is not a permanent resident on a single coral colony as the crabs can migrate between coral colonies with available space to provide them shelter and food [23] or when searching for partners for reproduction [7]. Although the basis of the symbiotic relationship between corals and crabs as well as the services that are provided are well characterized, so far, we still lack understanding regarding the initiation and stability of this symbiotic relationship, information that is necessary to identify and describe the recruitment-permanence process of Trapezia on Pocillopora and to recognize the key factors involved in it. This symbiosis cannot be fully understood without the basic knowledge of the individual organisms, which will then provide insights into the role of Trapezia for the presence and even ability of the coral to resist and/or respond to future climate change scenarios.

To provide insights on coral-Trapezia symbiosis over two years, we registered the beginning of the relationship in order to identify the factors involved in the recruitment and permanence of Trapezia crabs in Pocillopora corals and thus reach a better understanding of this symbiotic relationship. 


\section{Materials and Methods}

\subsection{Study Area}

Islas Marietas National Park (IMNP) is an insular natural protected area located in the Northeastern Tropical Pacific and consists of two islands (Isla Larga and Isla Redonda) and several islets (Figure 1) [24]. The region is characterized as an oceanographic transition area, with the seasonal convergence of three oceanic currents: Costa Rica Coastal Current, the California Current and the water mass of the Gulf of California [25]. Also, local conditions, such as the presence of seasonal upwelling, internal waves and runoffs influence the environmental conditions of the area $[26,27]$.

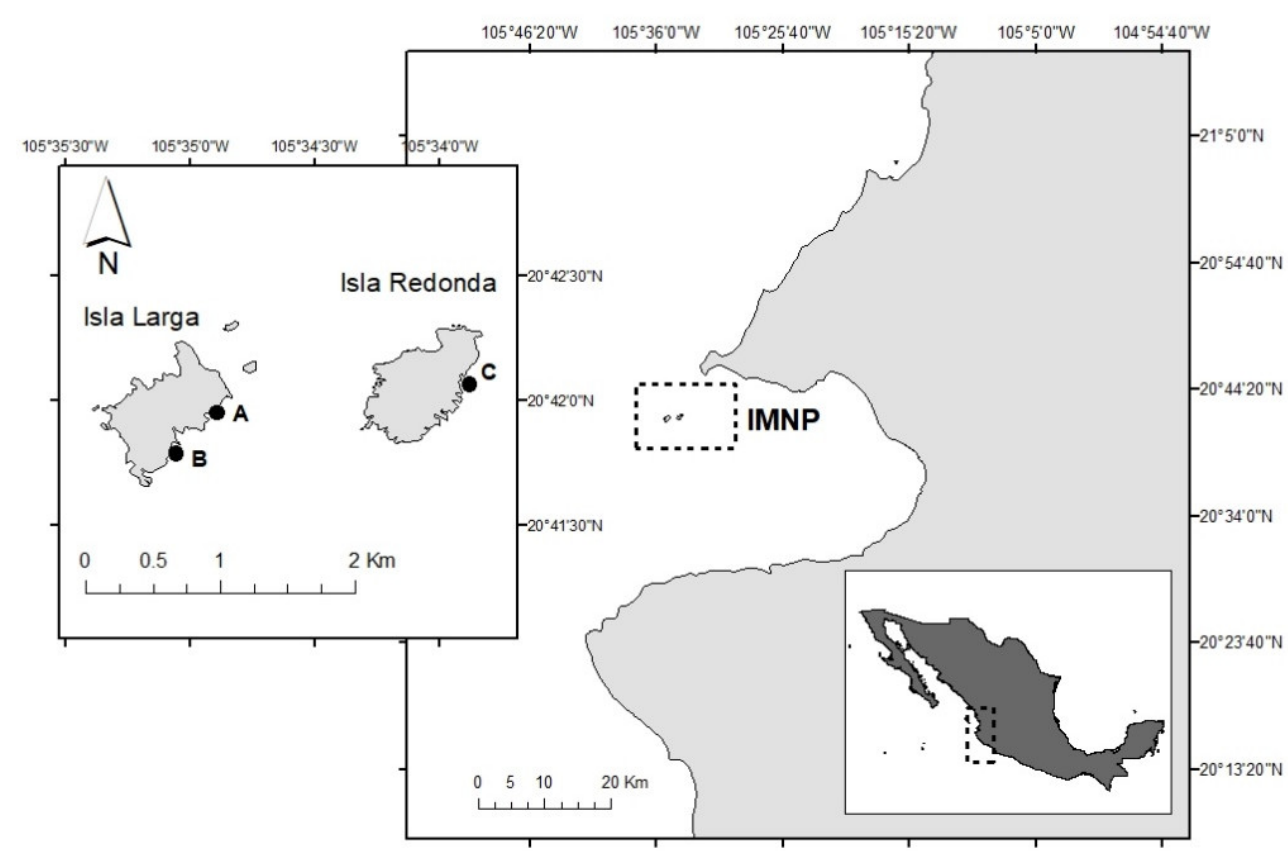

Figure 1. Study area: Islas Marietas National Park (IMNP), Nayarit, Mexico. All sampling sites harbor a high Pocillopora sp. coverage: (A) Restoration Zone $\left(20.698860^{\circ} \mathrm{N}, 105.580997^{\circ} \mathrm{W}\right)$ and (B) Cueva del Muerto $\left(20.697389^{\circ} \mathrm{N}, 105.582806^{\circ} \mathrm{W}\right)$ at Isla Larga, and (C) Pavonas Platform $\left(20.700908^{\circ} \mathrm{N}\right.$, $\left.105.565304^{\circ} \mathrm{W}\right)$ at Isla Redonda.

Regarding benthic fauna, IMNP harbors one of the most important coral communities of the Northeastern Tropical Pacific, composed mainly of branched corals of the genus Pocillopora [28] and distributed in a depth range between 0 and $20 \mathrm{~m} \mathrm{[24].} \mathrm{It} \mathrm{is} \mathrm{important} \mathrm{to}$ mention that Pocillopora is one of the most important reef builders in the Eastern Pacific [10], represented in the area by at least eight different morpho-species [29]. In addition to its high richness, this region is also considered an important larval dispersal and connectivity zone along the ETP [16].

For the purpose of this study and better spatial representation, three sites were selected. All sites harbor a high coral cover of healthy adult Pocillopora spp. colonies with a high availability of naturally fragmented corals also defined as fragments of opportunity: (1) Restoration Zone (RZ) and (2) Cueva del Muerto (CM), both located on Isla Larga and representing 11\% cover of Pocillopora corals, and (3) Pavonas Platform (PP) on Isla Redonda, with $\sim 9 \%$ cover, located at a depth of 6-8 $\mathrm{m}[29,30]$ (Figure 1$)$. The benthic communities at the sites include massive and sub-massive corals of the genus Porites and Pavona, as well as other important morpho-functional groups such as articulated and encrusting coralline algae, fleshy macroalgae, algal turf, sponges, coral rubble, other sessile groups, rock and sand [31]. 


\subsection{Field Experiment}

To evaluate the Trapezia recruitment rate and the relationship with the available space, a total of 44 Pocillopora fragments of opportunity $(\sim 8 \mathrm{~cm}$ length, $\sim 6 \mathrm{~cm}$ width) were hand-collected by SCUBA diving. Each fragment was visually evaluated in order to select only healthy coral fragments without evidence of bleaching, tissue damage or high abundance of external and internal bioeroders. More importantly, all fragments represented a single branch $(\approx 1 \mathrm{~cm}$ height) without associated Trapezia crab. To minimize the stress of transplantation, all fragments were carefully placed in plastic baskets and immediately transferred by divers to designated transplant areas. Each fragment was individually fixed to a rocky substrate with a plastic cable tie $[32,33]$ and then tagged so that individual growth and overall development of each coral colony and Trapezia recruitment could be monitored (Figure 2).
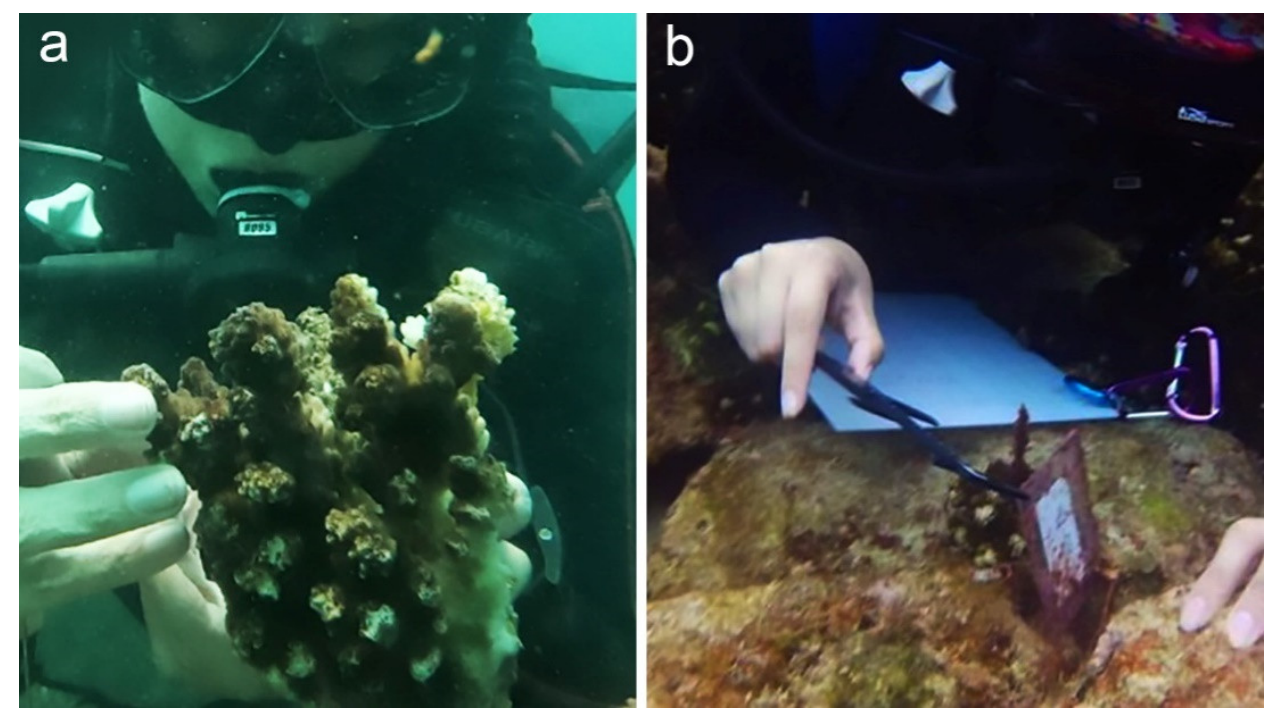

Figure 2. Coral fragment transplantation and monitoring. (a) Coral fragment selection; (b) Fixing and labeling of Pocillopora fragments without Trapezia.

Coral growth was measured every two months during a two-year period (September 2018-October 2020). For this, maximum length, width and height of coral fragments were measured with plastic calipers ( $0.05 \mathrm{~mm}$ precision) to estimate the volume and hence determine the habitat space available for recruitment, as described by Barry [34]. It is important to emphasize the relevance of the three-dimensional structure resulting from the growth pattern of Pocillopora. So far, fragmentation is considered the most important reproductive strategy of Pocillopora in the region [35]. Since the fragments originated from asexual reproduction (fragmentation), they initially did not show a complex growth, so a $1 \mathrm{~cm}$ height was used in the formula to calculate the volume until the fragments presented ramification and therefore an increase in their complexity.

Trapezia recruitment (Figure 3) was assessed over the two-year period by visually recording the abundance of the crabs per colony at every visit (bi-monthly) using a thin metal rod and inserting it into the spaces between the coral branches to trigger Trapezia defense response. Additionally, to evaluate the relationship between crab migration and available space, the distance of each transplanted fragment (colony) to the closest adult Pocillopora colony was measured. Also, daily sea temperature was recorded in situ by a $\mathrm{HOBO}$ temperature data logger (Onset, MA, USA) and the average value of the sampling time (month in which the visits were made to record data). Furthermore, bi-monthly mean sea surface temperature was calculated to evaluate the effect of temperature on crab recruitment. 

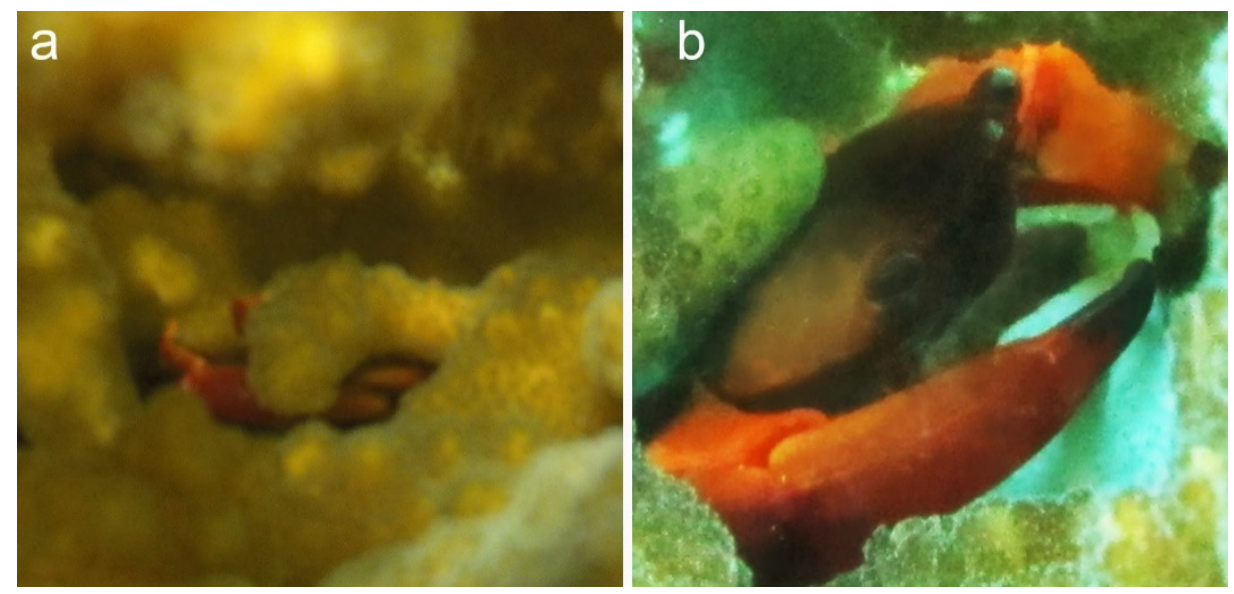

Figure 3. Recruitment of Trapezia in Pocillopora fragments. (a) Trapezia sp. hidden between coral branches; (b) Close up to Trapezia crab.

\subsection{Data Analysis}

Differences in Trapezia recruitment (density per colony) and habitat space (i.e., coral volume) through the sampling time were analyzed, each one with a one-way repeated measures analysis of variance (ANOVA) based on permutations and using the sampling time $(\mathrm{T})$ as a fixed factor. These repeated measures ANOVAs based on permutations were constructed with Euclidean distance matrices following Anderson et al. [36]. The main test and pairwise comparisons were assessed using 10,000 permutations of residuals based on a reduced model and type III sum of squares. Analyses were computed using PRIMER ver. 6.1.11 + PERMANOVA v.1.0.1 software [37].

A multiple linear regression (MLR) was performed to identify the explaining variables that best explained the Trapezia recruitment. Thus, coral volume and the sea temperature were independent variables, while Trapezia crabs' abundance was the dependent variable $\left[Y=\beta_{0}+\beta_{1} X_{1}+\beta_{2} X_{2}\right]$. Fit to the Gaussian curve and homoscedasticity were met from model residuals. MLR was done with SigmaPlot 11.2 software. In order to explore how the natural adult Pocillopora colonies on the site were related to the variation in Trapezia recruitment from the experimental transplanted coral fragments, we plotted an exploratory graph. The data used in the graph were the total abundance of Trapezia of each fragment over time and the distance of each transplanted coral fragment to the nearest adult colony.

\section{Results}

Pocillopora fragments showed a growth of $2.52 \pm 1.18 \mathrm{~cm} \mathrm{yr}^{-1}$ in length and $2.12 \pm 1.13 \mathrm{~cm} \mathrm{yr}^{-1}$ in width during the first year, and during the second sampling year, a growth of $4.55 \pm 1.43 \mathrm{~cm} \mathrm{yr}^{-1}$ in length and $4.59 \pm 1.91 \mathrm{~cm} \mathrm{yr}^{-1}$ in width. In both, the difference in annual coral growth and the consequent development of branches resulted in an almost twofold differential increase in the colony volumes during the first year $\left(42\right.$ to $\left.77 \mathrm{~cm}^{3}\right)$, while during the second year the colonies reached +10 -fold volume, with a maximum value of $1335 \mathrm{~cm}^{3}$.

The first evidence of crab recruitment was recorded two months after transplantation (first sampling time point) in fragments with a minimum volume of $20.13 \mathrm{~cm}^{3}$. During the study, a maximum of seven crabs per colony was observed. However, their permanence was not stable, as the number of crabs fluctuated in the colonies over time; therefore, the occupation was not permanent, since in coral colonies harboring crabs at one sampling time point, they could be absent in the next and present again in the following sampling time point, evidencing the ability of Trapezia to migrate between colonies (Table S1). Also, the distance between colonies was assessed with a maximum distance of $12.5 \mathrm{~m}$, suggesting that the crabs were able to move among coral colonies at distances $\geq 10 \mathrm{~m}$. Finally, the temperature data showed a sea temperature range of $19-31^{\circ} \mathrm{C}$. 
On the other hand, repeated measures ANOVAs based on permutations evidenced an increase of the colony volume over time (Figure 4, Table 1) and an increase of Trapezia recruited (Figure 5, Table 1).

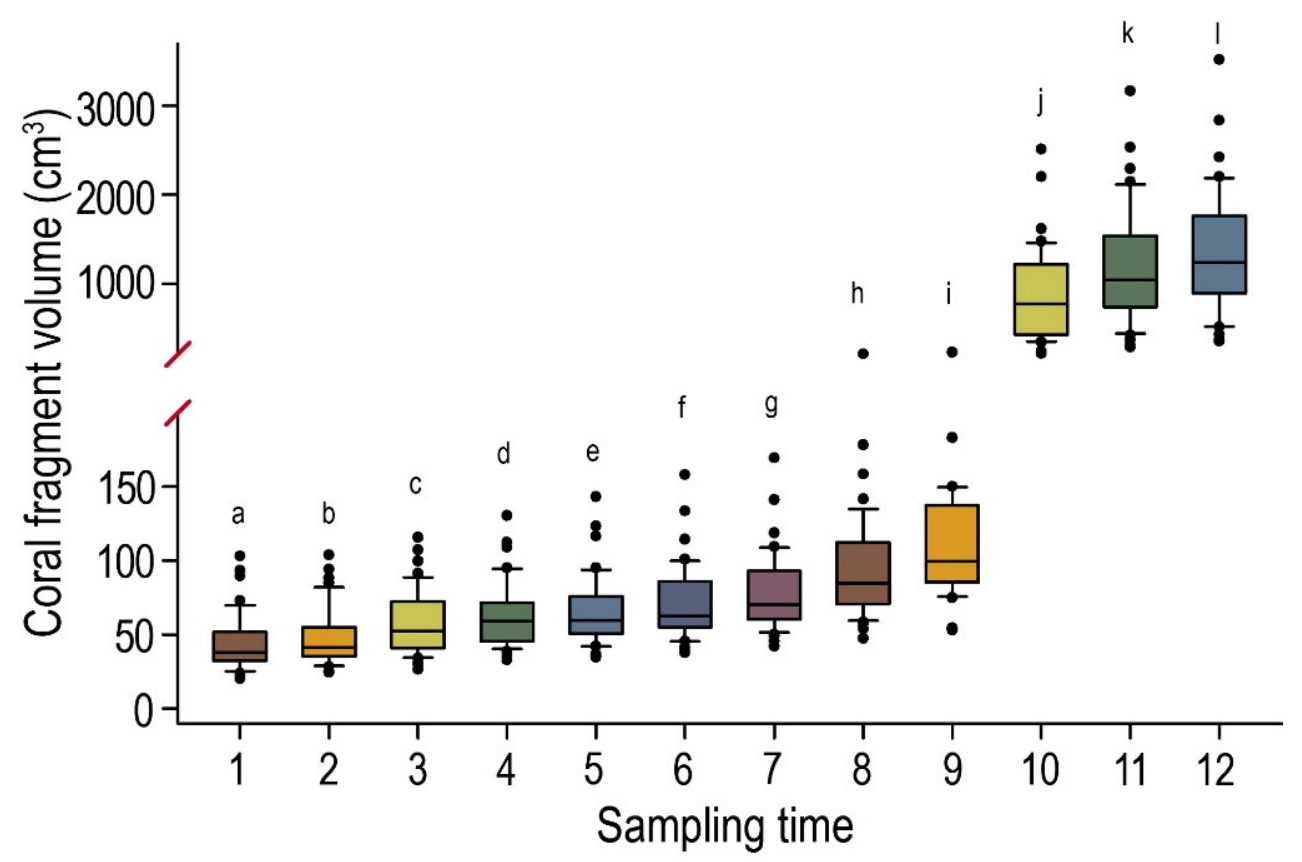

Figure 4. Boxplots of changes in colony volume over time. Corals were monitored bi-monthly for two years, with 0 representing the time when coral fragments were transplanted. The bars indicate the average (with the representation of the median) volume of fragments per time point. Y-Axis break was used to shrink a segment and enhance the readability of fragment volume change in the chart. Letters indicate significant differences between groups.

Table 1. One-way univariate ANOVA with repeated measures based on permutations evaluating differences in coral growth as the volume, and recruitment of Trapezia, between time (T).

\begin{tabular}{ccccccc}
\hline \multirow{2}{*}{ Source } & \multicolumn{3}{c}{ Habitat Space } & \multicolumn{3}{c}{ Recruitment } \\
\cline { 2 - 7 } & Pseudo-F & P (perm) & C.V.(\%) & Pseudo-F & P (perm) & C.V.(\%) \\
\hline Time & 145.44 & $0.0001 *$ & 71.7 & 108.1 & $0.0001 *$ & 70.9 \\
Residuals & & & 21.9 & & & 29.1 \\
\hline * & & &
\end{tabular}

${ }^{*}$ Results with statistical differences $(p<0.05)$.

The MLR was significant $(\mathrm{F}=10.417, p=0.005)$ with a $\mathrm{R}^{2}$ adj $=63 \%[\mathrm{Y}=15.993+(1.889$ * Temperature $)+(0.00183 *$ Volume $)]$ where coral volume was the best predictable variable $(t=4.265, p=0.002)$ for Trapezia recruitment and how this influence increases over time. Temperature alone was not significantly related to Trapezia recruitment $(t=0.823, p=0.432)$, but in combination with coral volume, it did generate a significant model ( $\mathrm{F}=10.417$, $p=0.005$ ). In addition, despite not being constant, a pattern of increase in the density of crabs was found with an evidently higher abundance of Trapezia with the increase of habitable space (coral volume) as a result of Pocillopora tridimensional growth and the development of branches. 


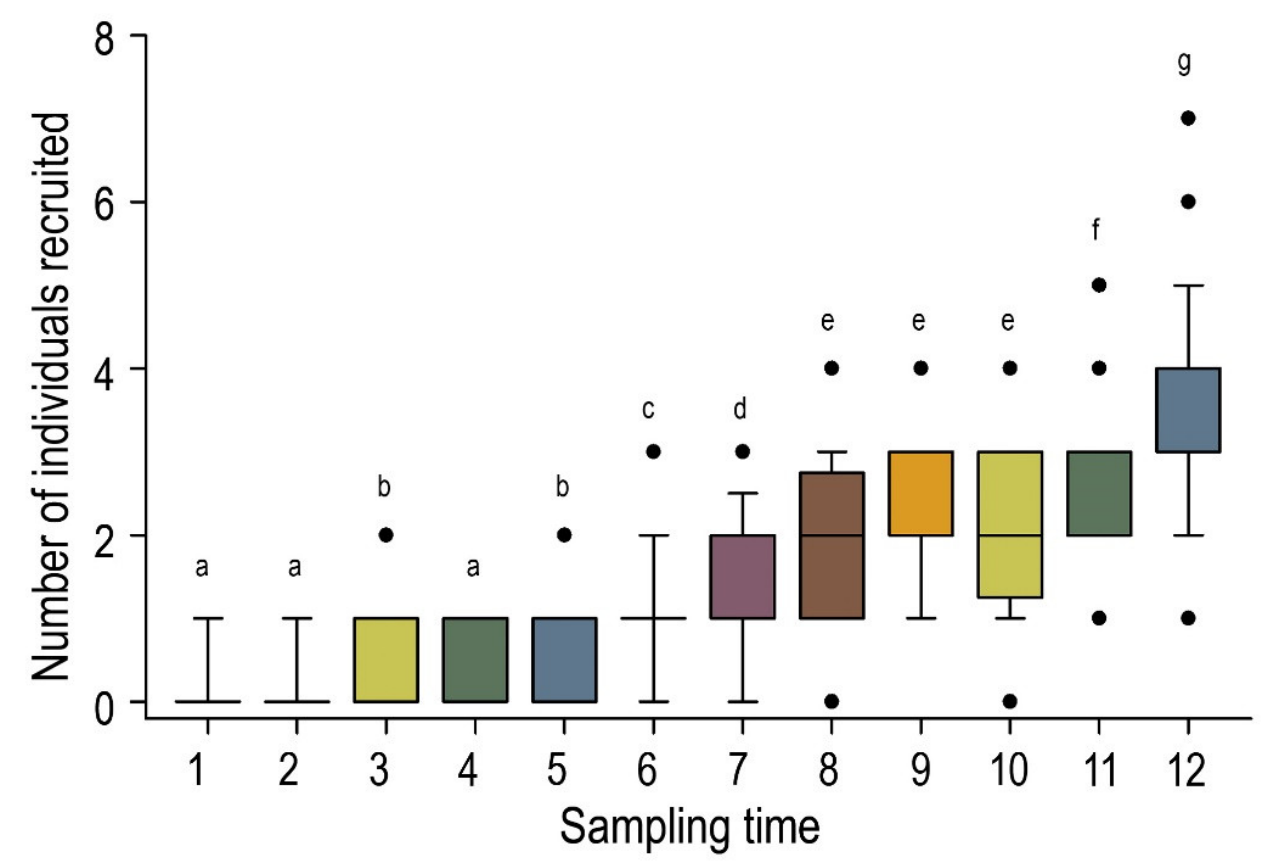

Figure 5. Boxplots of Trapezia crab's recruitment on Pocillopora fragments. A decrease or absence of Trapezia suggests migration between colonies. Letters indicate significant differences between groups.

\section{Discussion}

Crustaceans are considered the most abundant and diverse group of invertebrates associated with coral reefs [1] and Trapezia represents a high-richness and high-occurrence group [38]. Although the Trapezia-Pocillopora association and the role of both host-symbiont have been previously documented $[8,14,18,38-40]$, no information was available regarding the crab recruitment process. In order to initiate a symbiotic relationship, the presence of both organisms is necessary; however, in the case of the coral, a recently recruited colony does not represent a habitable space for Trapezia, and colony volume and associated available area has been determined as both a limiting and essential factor for the commensals $[34,39]$. The availability of sufficient space for the presence of Trapezia is not attributed to their nutritional requirements or reproductive activity but to the territorial and aggressive behavior that these crabs develop [41]. In the present study, the coral colonies show differences in their volume and thus available area, whilst no differences in the recruitment of Trapezia related to the volume of the coral were found. In this context, it could be hypothesized that the probability that Trapezia recruit a colony is related to the increasing complexity of its branching morphology and not the volume per se [40]. However, our findings showed that three-dimensionality was not necessary for crab recruitment; instead, the crabs only need a healthy coral fragment without secondary branching, even though this could result in increased Trapezia vulnerability due to being relatively unprotected against predators.

Also, independently of the presence of branches or the lack of structural complexity of the coral colonies, crabs were not permanent residents, as indicated by their fluctuating abundance per coral colony throughout the monitoring period. Previously, the territorial behavior of the crab had led to the assumptions that (1) the presence of more than a couple of crabs per colony would be related to the available area [39], (2) that there could be a hierarchy by space within the colony, with larger crabs displacing smaller crabs to the margins of the colony or entirely outside of it [42], as the recruitment of recent recruit crabs depends on an intra-species interaction where the conspecific resident crab should accept the new resident [43], and (3) that in addition to having a high energetic cost, movements or migrations among coral hosts would increase the vulnerability of the crabs to predators [44]. Therefore, besides the area and exposure factors, the distance between hosts, predation pressure, host characteristics (size, abundance), physical stress 
(temperature) and sex are key factors determining the balance between costs and possible benefits of colony fidelity $[7,45]$. Predation pressure can be related to the distance between hosts, i.e., when predation pressure is high [46] and distances between hosts increases, the crabs reduce or cease their movements [47]. Here it was observed that the distance between tagged and adult Pocillopora colonies was not a limiting factor to prevent the migration of Trapezia between hosts (Figure 6), suggesting that at the beginning of the symbiosis, Trapezia presents a random distribution among Pocillopora corals in the reef, and as the fragment grows, habitat space and complexity and other factors such as those mentioned above can modify the distribution and permanence of crabs.

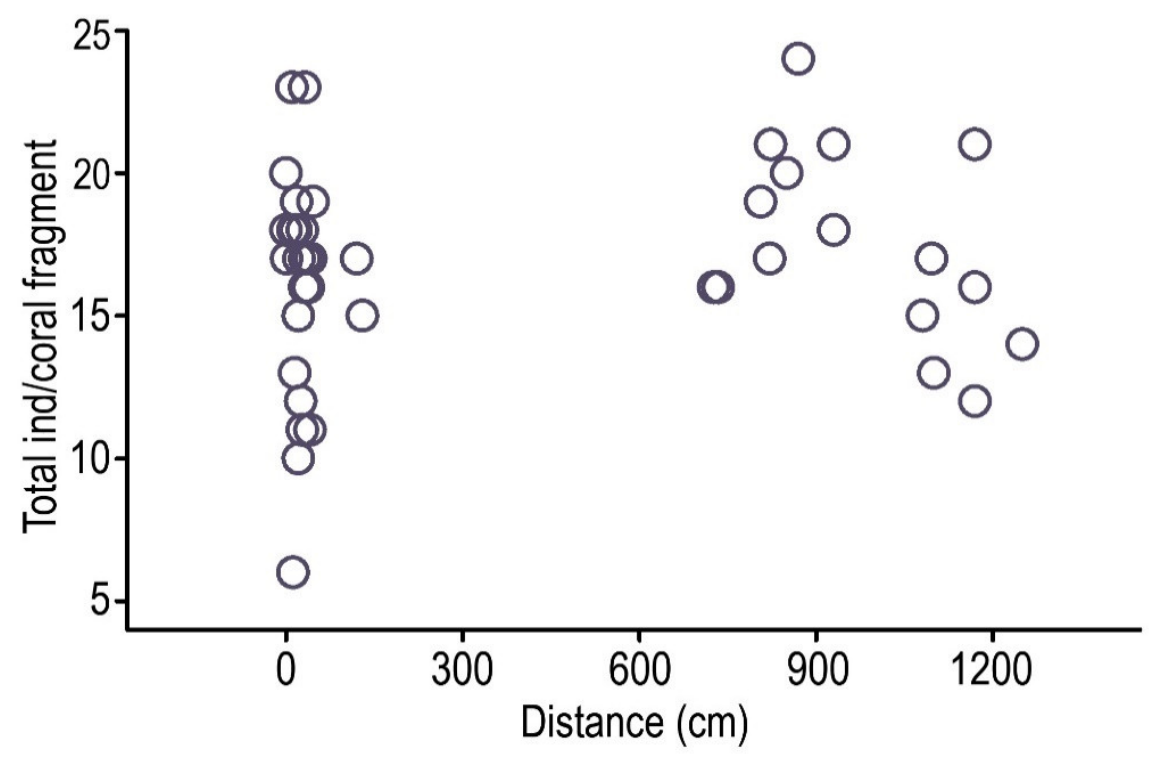

Figure 6. Distances between fragments. Distances represent migration between colonies, as there is no pattern between recruitment and distances; these do not influence the recruitment of Pocillopora colonies.

Temperature is one of the main environmental factors that affect physiological processes such as growth, reproduction and recruitment of crustaceans [48]. Even though Trapezia is able to acclimate its behavior, biochemistry and physiology in order to compensate for temperature fluctuations, after surpassing their thermo-tolerance limit, high-energy cost activities will be limited or as is the case of reproduction, can be inhibited [49]. Trapezia can present behavioral changes in situations of heat stress, leading these crabs to modify their role in their relationship with the coral, causing a break-down of the symbiosis and a shift from mutualistic antagonism towards an antagonistic relationship between members of coral-dwelling communities [50]. In this study, the presence of positive or negative thermal anomalies that could have caused a modification in the behavior of the crustaceans was not evidenced, though it was expected that seasonal changes in temperature would have affected crab recruitment. However, there were no significant changes in the recruitment process of Trapezia on Pocillopora, though it has been shown previously that invertebrate recruitment in sub-tropical coral communities does not present a seasonal pattern but may have intra-annual differences [22]. Therefore, this fluctuation in Trapezia recruitment may have been due to other biological interactions such as predation or the presence of secondary food sources (zooplankton).

The cause and, even more so, the persistence of the symbiotic relationship between the coral and the crustacean seems to be a highly complex process. Our results show that the presence, abundance and residence of Trapezia in Pocillopora were not determined by the physical characteristics of the substrate (area available) or by their reproduction patterns but were regulated by seasonal temperature fluctuations. Therefore, although the relationship between Trapezia and Pocillopora remains symbiotic [51] and the presence of 
the coral determines the distribution of the crab [52], there is not a permanent link at the coral-individual level. Still, understanding the process of recruitment and permanence of Trapezia on its host is relevant in determining their mutual subsistence. The TrapeziaPocillopora long-term relationship is primarily defined at the coral community level and not so much at the individual level (colony-crab). The degradation and decline of coral reefs ecosystems also threaten their associated organisms, and the traditional view includes that the permanence of Trapezia is regulated by their coral host Pocillopora; however, the functional roles of the crustacean as cleaners and protectors from different corallivores and diseases $[14,16]$ may contribute to the ability of Pocillopora to resist to multiple stressors and maintain the base of the coral community. Therefore, while healthy corals provide resources for the maintenance of Trapezia, at the same time, the presence of these crabs ensures the maintenance and permanence of Pocillopora and the biomass that directly depends on them.

Supplementary Materials: The following are available online at https: / www.mdpi.com/article / 10.3390 / d13090450/s1, Table S1: Density of recruited Trapezia crabs.

Author Contributions: Conceptualization, H.M.C.-F. and A.P.R.-T.; methodology, H.M.C.-F., A.P.R.-T. and A.L.C.-M.; formal analysis, F.A.R.-Z.; resources, A.P.R.-T. and A.L.C.-M.; writing-original draft preparation, H.M.C.-F. and A.P.R.-T.; writing-review and editing, H.M.C.-F., A.P.R.-T., F.A.R.-Z. and A.L.C.-M.; funding acquisition, A.P.R.-T. and A.L.C.-M. All authors have read and agreed to the published version of the manuscript.

Funding: H.M.C.-F. was funded by a doctoral fellowship from the Consejo Nacional de Ciencia y Tecnologia (CONACYT-No. 632506). The present work was supported by the National Geographic Society (NGS-55349R-19 to APRT) and the project "Programa Integral de Fortalecimiento Institucional" of the Universidad de Guadalajara (P/PIFI-2010-14MSU0010Z-10 to ACM).

Institutional Review Board Statement: Not applicable.

Informed Consent Statement: Not applicable.

Data Availability Statement: All data is included in the manuscript, there is no other data applicable for the purpose of the present manuscript.

Acknowledgments: We thank the authorities of the Islas Marietas National Park (CONANP) for their assistance with field operations Also, the authors thank Diana Morales and Ismael Huerta for image editing, Violeta Martinez for providing photographs of Trapezia crabs and Adolfo TortoleroLangarica for his help in fieldwork. A special thanks to Patricia Briones for her invitation in this Special Issue. Finally, we thank to Nadine Schubert for the English proofreading of the final version of the manuscript.

Conflicts of Interest: The authors declare no conflict of interest.

\section{References}

1. Glynn, P.W.; Enochs, I.C. Invertebrates and their roles in coral reef ecosystems. In Coral Reefs: An Ecosystem in Transition; Dubinsky, Z., Stambler, N., Eds.; Springer Press: Dordrecht, The Netherlands, 2011; pp. 273-325. [CrossRef]

2. Enochs, I.C.; Glynn, P.W. Corallivory in the Eastern Pacific. In Coral Reefs of the Eastern Tropical Pacific: Persistence and Loss in a Dynamic Environment; Glynn, P.W., Manzello, D.P., Enochs, I.C., Eds.; Springer: Berlin/Heidelberg, Germany, 2016 ; Volume 8. [CrossRef]

3. Garth, J.S. New brachyuran crabs from the Galapagos Islands. Allan Hancock Pac. Exped. 1939, 5, 9-49.

4. Garth, J.S. The Crustacea Decapoda (Brachyura and Anomura) of Eniwetok Atoll, Marshall Islands, with special reference to the obligate commensals of branching corals. Micronesica 1964, 1, 137-144.

5. Montano, S. The extraordinary importance of coral-associated fauna. Divers 2020, 12, 357. [CrossRef]

6. Karlson, R.H. Dynamics of Coral Communities, 1st ed.; Kluwer Academic Publishers: London, UK, 1999; pp. 40-55.

7. Castro, P. Movements between coral colonies in Trapezia ferruginea (Crustacea: Brachyura), an obligate symbiont of scleractinian corals. Mar. Biol. 1978, 46, 237-245. [CrossRef]

8. Stella, J.S.; Pratchett, M.; Hutchings, P.; Jones, G. Coral-associated invertebrates: Diversity, ecological importance and vulnerability to disturbance. Oceanogr. Mar. Biol. 2011, 49, 43-104.

9. Baeza, J.A. Crustaceans as symbionts: An overview of their diversity, host use and life styles. In Lifestyles and Feeding Biology. The Natural History of the Crustacea, 1st ed.; Thiel, M., Watling, L., Eds.; Oxford University Press: New York, NY, USA, 2015; Volume 2, pp. 163-189. 
10. Montano, S.; Fattorini, S.; Parravicini, V.; Berumen, M.L.; Galli, P.; Maggioni, D.; Arrigoni, R.; Seveso, D.; Strona, G. Corals hosting symbiotic hydrozoans are less susceptible to predation and disease. Proc. R. Soc. Lond. B Biol. Sci. 2017, 284, 20172405. [CrossRef]

11. Pratchett, M.S. Influence of coral symbionts on feeding preferences of crown-of-thorns starfish Acanthaster planci in the western Pacific. Mar. Ecol. Prog. Ser. 2001, 214, 111-119. [CrossRef]

12. Rouzé, H.; Lecellier, G.; Mills, S.C.; Planes, S.; Berteaux-Lecellier, V.; Stewart, H. Juvenile Trapezia spp. crabs can increase juvenile host coral survival by protection from predation. Mar. Ecol. Prog. Ser. 2014, 515, 151-159. [CrossRef]

13. Pollock, F.J.; Katz, S.M.; Bourne, D.G.; Willis, B.L. Cymo melanodactylus crabs slow progression of white syndrome lesions on corals. Coral Reefs 2013, 32, 43-48. [CrossRef]

14. McKeon, C.S.; Moore, J.M. Species and size diversity in protective services offered by coral guard-crabs. PeerJ 2014, 2, 574. [CrossRef] [PubMed]

15. Garth, J.S. Decapod crustaceans inhabiting reef-building corals of Ceylon and the Maldive Islands. J. Mar. Biol. Assoc. India. 1974, $15,195-212$.

16. Glynn, P.W.; Ault, J.S. A biogeographic analysis and review of the far eastern Pacific coral reef region. Coral Reefs 2000, 19, 1-23. [CrossRef]

17. Lee, S.Y. Ecology of brachyura. In Treatise on Zoology-Anatomy, Taxonomy, Biology. The Crustacea, 1st ed.; Castro, P., Davie, P.J.F., Guinot, D., Schram, F.R., von Vaupel Klein, J.C., Eds.; Brill: Boston, MA, USA, 2015; Volume 9, Part C (2 vols); pp. $469-541$.

18. Stewart, H.L.; Holbrook, S.J.; Schmitt, R.J.; Brooks, A.J. Symbiotic crabs maintain coral health by clearing sediments. Coral Reefs 2006, 25, 609-615. [CrossRef]

19. Mclay, C.L.; Becker, C. Reproduction in brachyura. In Treatise on Zoology-Anatomy, Taxonomy, Biology. The Crustacea, 1st ed.; Castro, P., Davie, P.J.F., Guinot, D., Schram, F.R., von Vaupel Klein, J.C., Eds.; Brill: Boston, MA, USA, 2015; Volume 9 , Part C (2 vols); pp. 185-243.

20. Hadfield, M.G. Biofilms and marine invertebrate larvae: What bacteria produce that larvae use to choose settlement sites. Annu. Rev. Mar. Sci. 2011, 3, 453-470. [CrossRef]

21. Sanford, E.; Kelly, M.W. Local adaptation in marine invertebrates. Annu. Rev. Mar. Sci. 2011, 3, 509-535. [CrossRef] [PubMed]

22. Rodríguez-Troncoso, A.P.; Rodríguez-Zaragoza, F.A.; Mayfield, A.B.; Cupul-Magaña, A.L. Temporal variation in invertebrate recruitment on an Eastern Pacific coral reef. J. Sea Res. 2019, 145, 8-15. [CrossRef]

23. Patton, W.K. Community structure among the animals inhabiting the coral Pocillopora damicornis at Heron Island Australia. In Symbiosis in the Sea, 1st ed.; Vernberg, W., Ed.; Univ. South Carolina Press: Columbia, SC, USA, 1974; pp. $219-243$.

24. CONANP (Comisión Nacional de Áreas Naturales Protegidas). Programa de Conservación Y Manejo, Parque Nacional Islas Marietas; Secretaria de Medio Ambiente y Recursos Naturales (SEMARENAT): México City, México, 2007; pp. 21-57.

25. Wyrtki, K. Surface currents of the eastern tropical Pacific Ocean. Bull. Inter-Am. Trop. Tuna Commn. 1965, 9, $268-305$.

26. Plata, L.; Filonov, A. Marea interna en la parte noroeste de la Bahía de Banderas México. Cienc. Mar. 2007, 33, 197-215.

27. Portela, W.; Beier, E.; Barton, E.D.; Castro, R.; Godínez, V.; Palacios Hernández, E.; Fiedler, P.C.; Sánchez-Velazco, L.; Trasviña, A. Water masses and circulation in the tropical pacific off Central Mexico and surrounding areas. J. Phys. Oceanogr. 2016, 46, 30693081. [CrossRef]

28. Reyes-Bonilla, H.; Calderón Aguilera, L.E.; Cruz-Piñón, G.; Medina-Rosas, P.; López-Perez, R.A.; Herrero-Perezrul, M.D.; LeyteMorales, G.E.; Cupul-Magaña, A.L.; Carriquiry-Beltran, J.D. Atlas de Corales Pétreos (Anthozoa: Scleractinia) del Pacifico Mexicano, 1st ed.; Sociedad Mexicana de Arrecifes Coralinos AC, CICESE, CONABIO, CONACYT, DBM/UABCS, CUC/UdeG, Umar: Mexico City, Mexico, 2005; p. 129.

29. Hernández-Zulueta, J.; Rodríguez-Zaragoza, F.A.; Araya, R.; Vargas-Ponce, O.; Rodríguez-Troncoso, A.P.; Cupul-Magaña, A.L.; Díaz-Pérez, L.; Ríos-Jara, E.; Ortiz, M. Multi-scale analysis of hermatypic coral assemblages at Mexican Central Pacific. Sci. Mar. 2017, 81, 91-102. [CrossRef]

30. Sotelo-Casas, R.C.; Rodríguez-Troncoso, A.P.; Rodríguez-Zaragoza, F.A.; Solís-Marín, F.A.; Godínez-Domínguez, E.; Cupul-Magaña, A.L. Spatial-temporal variations in echinoderm diversity within coral communities in a transitional region of the northeast of the eastern pacific. Estuar. Coast. Shelf Sci. 2019, 227, 106346. [CrossRef]

31. Cruz-García, R.; Rodríguez-Troncoso, A.P.; Rodríguez-Zaragoza, F.A.; Mayfield, A.; Cupul-Magaña, A.L. Ephemeral effects of El Niño-Southern Oscillation events on an eastern tropical Pacific coral community. Mar. Freshw. Res. 2020, 71, 1259-1268. [CrossRef]

32. Edwards, A.J. Reef Rehabilitation Manual; The Coral Reef Targeted Research and Capacity Building for Management Program: Queensland, Australia, 2010; pp. 64-108.

33. Tortolero-Langarica, J.J.A.; Cupul-Magaña, A.L.; Rodríguez-Troncoso, A.P. Restoration of a degraded coral reef using a natural remediation process: A case study from a Central Mexican Pacific National Park. Ocean Coast. Manag. 2014, 96, 12-19. [CrossRef]

34. Barry, C.K. Ecological Study of the Decapod Crustaceans Commensal with the Branching Coral Pocillopora meandrina var. Nobilis Verrill. Master's Thesis, University of Hawaii, Honolulu, HI, USA, 1965.

35. Highsmith, R.C. Reproduction by fragmentation in corals. Mar. Ecol. Prog. Ser. 1982, 7, 207-226. [CrossRef]

36. Anderson, M.J.; Gorley, R.N.; Clarke, K.R. PERMANOVA+ for PRIMER: Guide to Software and Statistical Methods; PRIMER-E: Plymouth, UK, 2008; p. 214.

37. Clarke, K.R.; Gorley, R.N. Primer V6: User Manual/Tutorial; PRIMER-E: Plymouth, UK, 2006; p. 192.

38. Castro, P. Animal symbioses in coral reef communities: A review. Symbiosis 1988, 5, 161-184. 
39. Abele, L.G.; Patton, W.K. The size of coral heads and the community biology of associated decapod crustaceans. J. Biogeogr. $1976,35-47$. [CrossRef]

40. Stewart, H.L.; Price, N.N.; Holbrook, S.J.; Schmitt, R.J.; Brooks, A.J. Determinants of the onset and strength of mutualistic interactions between branching corals and associate crabs. Mar. Ecol. Prog. Ser. 2013, 493, 155-163. [CrossRef]

41. Preston, E.M. A computer simulation of competition among five sympatric congeneric species of xanthid crabs. Ecology 1973, 54, 469-483. [CrossRef]

42. Huber, M.E. Aggressive behavior of Trapezia intermedia miers and T. digitalis Latreille (Brachyura: Xanthidae). J. Crust. Biol. 1987, 7, 238-248. [CrossRef]

43. Vannini, M. A shrimp that speaks crab-ese. J. Crust. Biol. 1985, 5, 160-167. [CrossRef]

44. Roughgarden, J. Evolution of marine symbiosis-A simple cost-benefit model. Ecology 1975, 56, 1201-1208. [CrossRef]

45. Thiel, M.; Zander, A.; Baeza, J.A. Movements of the symbiotic crab Liopetrolisthes mitra between hosts, black sea urchins Tetrapygus niger. Bull. Mar. Sci. 2003, 72, 89-101.

46. Knowlton, N. Sexual selection and dimorphism in two demes of a symbiotic, pair-bonding snapping shrimp. Evolution 1980 34, 161-173. [CrossRef]

47. Bell, J.L. Changing residence: Dynamics of the symbiotic relationship between Dissodactylus mellitae Rathbun (Pinnotheridae) and Mellita quinquiesperforata (Leske) (Echinodermata). J. Exp. Mar. Biol. Ecol. 1984, 82, 101-115. [CrossRef]

48. Hartnoll, R.G.; Bryant, A.D. Growth to maturity of juveniles of the spider crabs Hyas coarctatus Leach and Inachus dorsettensis (Pennant) (Brachyura: Majidae). J. Exp. Mar. Biol. Ecol. 2001, 263, 143-158. [CrossRef]

49. Azra, M.N.; Aaqillah-Amr, M.A.; Ikhwanuddin, M.; Ma, H.; Waiho, K.; Ostrensky, A.; Prestes dos Santos Tavares, C.; AbolMunafi, A.B. Effects of climate-induced water temperature changes on the life history of brachyuran crabs. Rev. Aquac. 2020, 12, 1211-1216. [CrossRef]

50. Stella, J.S.; Munday, P.L.; Walker, S.P.W.; Pratchett, M.S.; Jones, G.P. From cooperation to combat: Adverse effect of thermal stress in a symbiotic coral-crustacean community. Oecologia 2013, 174, 1187-1195. [CrossRef] [PubMed]

51. Tsuchiya, M.; Taira, A. Population structure of six sympatric species of Trapezia associated with the hermatypic coral Pociliopora damicornis with a hypothesis of mechanisms promoting their coexistence. J. Jpn. Coral Reef Soc. 1999, 9-17. [CrossRef]

52. Knudsen, J.W. Trapezia and Tetralia (Decapoda, Brachyura, Xanthidae) as obligate ectoparasites of pocilloporid and acroporid corals. Pac. Sci. 1967, 21, 51-57. 